\title{
State Polytechnic Students' Perception on General English Subjects
}

\author{
Iis Sulyaningsih \\ Department of English, Politeknik Negeri Bandung \\ Bandung, Indonesia \\ E-mail: iis.sulyaningsih@polban.ac.id
}

\begin{abstract}
This paper discusses the Bandung State Polytechnic Students' perception towards General English classes (General English 1 and General English 2). The research is aimed to investigate the students' perception towards the materials given in General English 1 and General English 2 classes. The survey was carried out to 110 students from 2 engineering classes and 2 non-engineering classes. This research applied quantitative method that used questioners to gain the data. Thus, the data were analyzed by applying SPSS, and the result shows that students' perception on General English1 subject is different from their perception on General English 2 subject.They perceive thatGeneral English1 subject provides important basic skill for communication in English, however it needs improvement in some materials for there are some students doubt about it. On the other hand, students think that the materials in General English 2 do not reach their needs and expectations. Accordingly, General English in Bandung State Polytechnic needs to be developed.
\end{abstract}

Keywords: English, General English, Polytechnic Curriculum

\section{INTRODUCTION}

Polytechnic is vocational higher education or competence-based education. This means that polytechnic provides the program both cognitive knowledge and skill related to competences needed at work place. In other words, vocational education is resulted from the need of having a job, it tends to the education for earning a living (Finch \& Crunkilton, 1999; Singh, M., 2009; Pavlova, M., 2009). According to Thompson (1973:150), thephilosophy of vocational education is "Matching": what job was needed and what was needed to do the job. Therefore, the needs of students on their jobs have to be considered indeveloping curriculum for Polytechnic program in order to result readiness semi-professional workers for industry.

There are two factors that support workers to succeed in their career; cognitive skills as hard skill and soft skill. According to Ellis (1980) soft skill or interpersonal skills" isinterpersonal professional that refers to workers ability to have direct interaction with their colleaguesat work place. Furthermore, soft kill is the ability to 
interact and to work in a team (team building), to have a good leadership, to solve working problem and to have a good communication skill. Having English language competence will help the workers to have better communication skill and to be more qualified.

In this case, Bandung State Polytechnic which results graduates who have cognitive skills and competence should support them with soft skill to be more competitive. Accordingly, Bandung State Polytechnic has designed its curriculum with English subjects to facilitate all students having English communication ability. The English subject is included in institutional curriculum to characterize institution. This curriculum is developed to support the core curriculum as its content in supporting subjects. There are English subjects included in this curriculum, they are General English 1 (Bahasa Inggris 1) and General English 2 (Bahasa Inggris 2). General English 1 is designed to carry verbal competence or speaking whereas General English 2 is intended to facilitatestudents to have reading ability. However, they are developed by the assumption that students need English competency in a future or workplace without any need analysis .

The recent study focuses on investigating students' perception towards the content of the subjects included inGeneral English 1 (Bahasa Inggris 1) and General English 2 (Bahasa Inggris 2). This is to discover whether those subject's contents have fulfilled their basic needs in developing their English competences. Regarding to this, there are hypotheses to be answered by conducting this research. The hypotheses are :

○ Ho : There is no different students perception towards General English 1 and Students' perception towards General English 2;

○ Ha: There is different students perception towards General English 1 and Students' perception towards General English 2;

$\circ$ and the research question is to what extent is the students perception towards General English 1 and General English 2.

At the end, the result of this research can be considered as the evaluation of curriculum and can be the base in revising and developingthe better contents for those subjects. 


\section{LITERATURE REVIEW}

This recent study is purposed to discover students' perceptions towards General English subjects. Perception refers to the inner unconscious feelings from which students'attitudes towards learning a language emanate 9 (Despagne, 2010). Based on the research,Suhaily Abdullah and Faizah Abd Majid (2013) concludes that perception towards students is the main factor that forms the teaching and also the teaching approach which based on students' responds. Accordingly, the respond and the students' perspective towards the subjects will influence teaching approach andwill affectthe subjects provided in the curricula.

In the case of the needed English content for Indonesian students has been studied Beryl Exley (2011), Centre for Innovation in Education, QUT A. The research that used case study is purposed to discover the appropriate knowledge and teaching model in the teaching of English as Foreign Language (EFL).This research discovered that the content focused on more general aspects of English language communication and on everyday life in these circumstances, the content knowledge that the teachers drew on were knowledge of everyday skills and specialized knowledge of general propositions.

The content of subjects on curriculum should be designed to fulfill the needs of language of students. However, this is not easy as the studentshave different characteristics and different style in learning. Therefore, research and analysis are required to be conducted by teachers to find the needs so that teacher can improve their teaching fulfilling students' need of English. This present research is also conducted to see whether the contents of General English subjects have fulfilled students' needs.

\section{English in communication}

Language is a means of communication, it helps human to convey messages or information and also to express feeling and an idea so that it builds interaction and forms social communication in a community. In global community, most countries use English to communicate in any sectors, education, technology and also trading and business. Therefore, our generation must be capable to make use ofit.

English competence plays an important role in developing qualified human resource for nation. Young generation have to be able to communicate in English. Furthermore, they can compete in global market that is happening in recent years. 
Realizing that English is important for young generation, the government has decided to put English as material content in the educational curriculum as an English as a Foreign Language. This is in line with Alwasilah's (2001) statement that English should have been part of curriculum as it supports the development of Indonesian young generation.

\section{English as a Subject in Education of Indonesia}

English has been put as a subject matter into Indonesia educational curriculum since 1967 which was emphasized on reading skill to enable students to access more knowledge and technology. Then, in 1984, communicative approach was employed in implementing the curriculum. However, the implementation of this curriculum was still in reading and grammar so this did not support students to be able to communicate orally. In 1994, curriculum was revised and applied meaning-based curriculum but the limitation of materials and the lack of students' backgroundknowledge became the barrier for students to express their ideas. In the next curriculum, the learning of English was based on Contextual Teaching-Learning which provided students to have an opportunity to build their own knowledge in line with their experiences. This curriculum changes the learning paradigm that is knowledge transformationconcept tobe knowledge construction conceptwhich applied Students Learning Centered (SCL) as the learning approach.

Curriculum is renewed in 2013. In this curriculum English learning is purposed to enable students having English competence as a means of communication. Students have to read and understand the text, then they summarize it to be presented in their own language. They are taught and practiced to write the text effectively and logically. They are also introduced to the rules of text and practiced to express their knowledge (The Guidelines on Curriculum Training/ Pedoman Diklat Kurikulum,2013).

\section{English as a Subject Matter in Polytechnic Curriculum}

Polytechnic provides students both hard skills and soft skill which is communication in English is one of them. To achieve the purpose, curriculum that emphasized on skills is designed. In other words, polytechnic curriculum focuses on competences included English competence to support students in their work place. Curriculum for higher education or Kurikulum Perguruan Tinggi (KPT)in POLBAN, was designed by constructing learning outcomes competences refered toKerangka 
Kualifikasi Nasional Indonesia (KKNI) inPeraturan Presiden No. 8 Tahun 2012. One of the competences that have to be mastered by the graduation from Diploma ( D3) program is to be able to communicate effectively. Therefore, POLBAN set English which are General English 1 and General English 2 as institutional curriculum obliged to all POLBAN students. To provide more knowledge and experiences to students, studies program provides them with English for Specific Purposes (ESP).

This Study investigates the students perception towards General English Subjects at to notice whether those subjects has been fulfilled their needs to support their communication in English.

\section{METHODOLOGY}

This study was conducted in quantitative method, thus the data were gained by distributing questioners to the research objects. The population of this study is the students of POLBAN students who have accomplished General English 1 and General English 2. Then, the sample is four classes which are 110 students from two engineering and two non-engineering classes. As mentioned previously, this research employedthe questioners in Likertscaleas research instruments in getting the accurate data on students' perception. The questioners consisted thirtynumbers of questions related to General English 1 and 18 numbers of questions related to for-General English 2 , and they scored as follow;

1. TA : Totally Agree 5

2. A : Agree 4

3. Uc : Uncertain 3

4. D : Disagree 2

5. TD: Totally Disagree 1

The collected data were analyzed as follow; first they were tallied and organized into a table, then they were analyzed using SPSS ANOVA (chi-square test) to discover the answer of research hypotheses. 
To interpret the result, the percentage clarified as follow;

\begin{tabular}{ll} 
Percentage & Clarification \\
\hline $90 \%-100 \%$ & Very High \\
\hline $80 \%-89 \%$ & High \\
\hline $70 \%-79 \%$ & Good \\
\hline $60 \%-69 \%$ & Average \\
\hline $50 \%-59 \%$ & Low \\
\hline$>49 \%$ & Very Low
\end{tabular}

\section{RESULT}

This research was conducted to get the answers of the following hypotheses and research question. The Hypotheses are:

○ Ho : There is no different students perception towards General English 1 and Students' perception towards General English 2;

O Ha: There is different students perception towards General English 1 and Students' perception towards General English 2;

$\circ$ and the research question is to what extent is the students perception towards General English 1 and General English 2.

The answer to hypotheses; Students perception towards General English 1 and General English 2.

To answer those hypotheses, Chi square teston the gaineddata was made and the result can be seen on the following table.

Tabel 1 Chi-Square Tests

\begin{tabular}{|l|r|r|r|}
\hline & Value & Df & $\begin{array}{c}\text { Asymp. Sig. (2- } \\
\text { sided) }\end{array}$ \\
\hline Pearson Chi-Square & $25,147^{\mathrm{a}}$ & 3 &, 000 \\
Likelihood Ratio & 27,908 & & 3 \\
N of Valid Cases & 107 & & \\
\hline
\end{tabular}

a. 2 cells $(25,0 \%)$ have expected count less than 5 . The minimum expected count is, 49 . 
The table shows that the significant value is 0,000 which tells that $\mathrm{Ha}$ is accepted. Thismeans that students perception towards General English 1 is different from students' perception towards General English 2.

The answer to the research question: to what extent is the students' perception towards General English 1?

General English 1 subject consists of:

○ Greeting and Introducing him/herself and others;

- Describing People's Physical Appearance And Character, Describing Places, Describing Jobs, Describing Objects And Its Function, Telling Numbers And Simple Calculation, Describing Process;

○ Asking For And Giving Directions, Requesting And Offering, Asking For And Giving Opinions, Asking For And Giving Reasons, Agreeing And Disagreeing, Dan Giving And Following Instructions.

Data for each statement are analyzed applying SPSS and the results are presented in the table. The table below is one example of the results that is taken randomly.

Tabel 2STATEMENT 28: "Learning how to agree and disagree is important for me"

\begin{tabular}{|c|c|c|c|c|c|}
\hline & & Frequency & Percent & Valid Percent & $\begin{array}{l}\text { Cumulative } \\
\text { Percent }\end{array}$ \\
\hline \multirow{6}{*}{ Valid } & TOTALLY DISAGREE & 1 & ,4 & ,9 & ,9 \\
\hline & DISAGREE & 2 & ,9 & 1,8 & 2,7 \\
\hline & UNCERTAIN & 9 & 4,0 & 8,2 & 10,9 \\
\hline & AGREE & 59 & 26,2 & 53,6 & 64,5 \\
\hline & TOTALLY AGREE & 39 & 17,3 & 35,5 & 100,0 \\
\hline & Total & 110 & 48,9 & 100,0 & \\
\hline Missing & System & 115 & 51,1 & & \\
\hline Total & & 225 & 100,0 & & \\
\hline
\end{tabular}

The results for data statistics on each statements are concluded that the students arehighly agree that General English 1is very important for them as the basic skills 
supporting their English communication competence. However, some students still uncertain and disagree to some statement. This indicates that there are still weaknesses in several materials and this needs to be review and revise to the better curriculum and better implementation.

\section{To what extent is the students' perception towards General English 2?}

General English 2 consists of:

1. Previewing and predicting

2. Contextual references

3. Scanning and Skimming

4. Types of Sentences

5. Paragraph

6. Theme, topic sentence and main ideas
7. Paragraph Patterns

8. Cause and Effect

9. Comparison and Contrast

10. Summarizing

11. Unity, Cohesion and Coherence

12. Text types

13. Mind Mapping

One example of statistic data for this subject can be seen below;

Statement 16: "I am able to acknowledge type of text (genre)"

\begin{tabular}{|c|c|c|c|c|c|}
\hline & & Frequency & Percent & Valid Percent & Cumulative Percent \\
\hline \multirow{5}{*}{ Valid } & 2 & 6 & 2,7 & 5,3 & 5,3 \\
\hline & 3 & 51 & 22,7 & 45,1 & 50,4 \\
\hline & 4 & 52 & 23,1 & 46,0 & 96,5 \\
\hline & 5 & 4 & 1,8 & 3,5 & 100,0 \\
\hline & Total & 113 & 50,2 & 100,0 & \\
\hline Missing & System & 112 & 49,8 & & \\
\hline Total & & 225 & 100,0 & & \\
\hline
\end{tabular}

Based on analysis of statistic data, it can be concluded that students' perception towards General English 2 is not as good as their perception towards students General English 1. Many students are still uncertain or disagree with some statements which pose the importance or the need of materials. The percentage of students who gave 
positive response on General English 2 is less than positive response to General English1.

\section{CONCLUSIONS AND RECOMMENDATIONS}

\section{Conclusions}

The research which focused on students' perspective towards General English 1 and General English 2 has not been done before. Thus, this research is preliminary study for discovering whether the curriculum has been appropriate. The result of this research become the basic knowledge for further research to maintain the best result of problem solution or to develop better curriculum for General English 1 and General English 2 in Bandung State Polytechnic.

The research discovered thatt students'perception towards General English 1 is good or positive. Many of students think that most of General English content is important for them so that they need to learn them. However, some students still uncertain and disagree with th subjects. On the other hands, students 'perception towards General English 2 subject indicates that many content of the subjects are not important for them. In conclusion, students perception towards General English 1 is different from students' perception towards General English 2.

\section{Recommendations}

The result of this study has been presented in the previous part; students perception towards General English 1 is different from students' perception towards General English 2. Based on the data analysis, It is found that the content of General English 2 get negative perception from students' position. This means, General English 2 which consist of reading technic should have more attention. As mentioned before, this study is preliminary study that can be seen as an evaluation to the subjects to be the basic data for developing better curriculum, especially for General English. This is to fulfill students need in basic skill for developing their communication competence. Therefore, the other research are needed to see the problem more detail from different aspects such as teaching methods, the resource, kinds of practice material, etc. The 
result of this study can also the fundamental for developing General English subject related to other study program so that it will fulfill and in line with the students' need.

English competence is important for POLBAN graduation so that they can compete positively in a global market. Consequently, the English classes should be provided continuously, every semester. Thus, POLBAN graduation with good English competence will have high confidence to compete in their job nationally and internationally.

\section{REFERENCES}

Adhikary, P.K. (2005). Educational Reform for Linking Skills Development With Employment In Nepal. In M. SINGH (Eds.), Meeting Basic Learning Needs in the Informal Sector Integrating Education and Training for Decent Work, Empowerment and Citizenship (pp. 215-228). Hamburg, Germany: UNESCO Institute for Education.

Alwasillah, A.C. (2004). Perspektif Pendidikan Bahasa Inggris di Indonesia, CV. Andira, Bandung, Indonesia.

Amal Ali Alkaff, (2013) Student's attitudes and Perceptions towards Learning English, King Abdul Aziz University, AWEJ Volume 2

Beryl Exley (2011) Indonesian EFL Curricula: What content knowledge demands do they make of Australian teachers?,Centre for Innovation in Education, QUT

Finch \& Crunkilton, (1979), Curriculum Development in Vocational and Technical Education, Allyn and Bacon, Massachusetts

Keraf (2004) Komposisi: Sebuah Pengantar Kemahiran Bahasa.Flores: Nusa Indah

Kountur, R.(2005) Metode Penelitian Untuk Penulisan skripsi dan Tesis. Cetakan ketiga. PPM. Jakarta

Kridalaksana, H. (2001). Kamus Linguistik. Jakarta: Gramedia Pustaka Utama 
Pavlova M. (2009). The Vocationalization of Secondary Education: The Relationships between Vocational and Technology Education. InR. Maclean, D. Wilson, \& C. Chinien (Eds.), International Handbook of Education for the Changing World of Work, Bridging Academic and Vocational Learning (pp. 1805-1822). Germany: Springer.

Putu Sudira, (2011) , Kurikulum Dan Pembelajaran Pendidikan Dan Pelatihan Vokasi

Singh M. (2009). Overview: Education and Training in the Informal Sector. InR. Maclean, D. Wilson, \& C. Chinien (Eds.), International Handbook of Education for the Changing World of Work, Bridging Academic and Vocational Learning (pp. 235-244). Germany: Springer.

Singh M. (2009). Social and Cultural Aspects of Informal Sector Learning: Meeting the Goals of EFA.InR. Maclean, D. Wilson, \& C. Chinien (Eds.), International Handbook of Education for the Changing World of Work, Bridging Academic and Vocational Learning (pp. 349-364). Germany: Springer

Sugiyono (2012) Metode Penelitian Kuantitatif Kualitatif dan R\&D. Bandung: Alfabeta. Suhaily Abdullah. Faizah Abd Majid,2014, Reflection on Language Teaching Practice in Polytechnic: Identifying Sources of Teachers' Beliefs hhtps://doi.org/10.1016/j.econdurev.2014.06.003

Thompson, John F, (1973). Foundation of Vocational Education Social and Philosophical Concepts.New Jersey: Prentice-Hall.

WardimanDjojonegoro. (1998). Pengembangan Sumber daya Manusia melalui SMK. Jakarta : PT. JayakartaAgung Offset. 